\title{
CRITICAL LEGAL THEORY IN CENTRAL AND EASTERN EUROPE: IN SEARCH OF METHOD
}

\begin{abstract}
Critical legal theory emerged in the United States in the 1970s, at a time when Central and Eastern Europe belonged to the Soviet bloc and was subject to the system of actually existing socialism. Therefore, the arrival of critical jurisprudence into the region was delayed. In Poland, the first texts on critical and postmodern legal theory began to appear at the end of the 1990s and the beginning of the 2000s. Lech Morawski's monograph, characteristically entitled What Legal Scholarship Has to Gain from Postmodernism?, published in 2001, officially inaugurated a broader interest in postmodern legal theory. Adam Sulikowski has been the main representative of critical legal theory in Poland, developing a postmodern theory of constitutionalism. Other sub-fields of postmodern and critical legal theory, gradually developing in Central European jurisprudence, include such areas as law and literature, law and ideology, law and neocolonial theory, as well as feminist jurisprudence. There is a noticeably growing influence of critical sociology and critical discourse analysis which seem to be a promising paradigm for invigorating critical legal theory from an empirical perspective. The concept of "the political", in the sense used by Chantal Mouffe, has been evoked to propose a "political theory of law" conceived as an analysis of the juridical phenomenon through the lens of the political. Recently, it has found its concrete applications in the political theory of judicial decision-making.
\end{abstract}

Keywords: critical legal theory, the political, law and ideology, Central and Eastern Europe.

Central and Eastern Europe has a specific history which differentiates it from Western Europe: in the $19^{\text {th }}$ century most of the states of the region did not exist, but were dominated by neighbouring empires. Later on, in the $20^{\text {th }}$ century all countries of the region went through the experience of actually existing socialism. These two factors alone have had a great impact upon our legal cultures. First of all, our legal cultures are young ones, as most of the states in the region emerged, in their modern form, in the $19^{\text {th }}$ or $20^{\text {th }}$ century, and others - such as Russia - were deeply transformed by the October Revolution (1917) and the dissolution of the Soviet Union (1991), which effectively broke any continuity with the pre-revolutionary legal culture. In contrast to the United Kingdom, France or

* University of Amsterdam, Faculty of Law, Centre for the Study of European Contract Law, r.t.manko@uva.nl

The present paper reflects exclusively the personal views of the author and does not present the position of any institution. I would like to thank the anonymous peer reviewer for their constructive and helpful comments on the present paper. 
Germany, we cannot boast a long tradition of legal culture, with subsequent generations of legal scholars emerging from within well established schools of jurisprudence. The story of glossators being succeded by commentators, commentators by the elegant jurisprudence, elegant jurisprudence by the pandctists and so forth - is not ours, for better or for worse.

However, what may seem prima facie as a disadvantage can also be turned into an advantage. The relative freshness of our legal communities, including our legal academia, means that especially the young generation of Central and Eastern European jurists is very open to new theoretical trends, even if they come to us 30 or 40 years later than in the West. This is exactly the case with critical legal theory. This strand of jurisprudence emerged in the United States in the mid 1970s and had its heyday in the 1980s. In the 1980s, it became popular in the United Kingdom (Douzinas 2014). But in our region everything came later. Just like the reception of postmodern legal thought into the humanities was delayed, so was - even more - the reception of critical legal theory. Effectively, the first Polish jurisprudential work on law and postmodernism was authored in 1999 by Bartosz Wojciechowski (Wojciechowski 1999), and the doors to postmodernism in legal theory were officially wide-opened only two years later by Lech Morawski in his programmatic monograph-manifesto entitled What Legal Scholarship Has to Gain from Postmodernism? (Morawski 2001). The early 2000s brought a whole plethora of writings on the subject, especially by Adam Sulikowski (2006a, 2006b, 2007a, 2007b, 2010a, 2010b), and Słamomir Oliwniak (2004, 2006, 2009, 2010, 2011). However, it was the first of them - Adam Sulikowski - to become the main representative of critical legal theory in Poland, with his ground-breaking works on postmodernism and constitutionalism (Sulikowski 2012a) and jurisprudence and posthumanism (Sulikowski 2013) which have set the trend not only in Polish, but more generally Central European critical legal studies. A symbolic recognition of this role was the organisation of the $30^{\text {th }}$ Critical Legal Conference - the annual gathering of English-speaking crtitical legal scholars - at the University of Wrocław (Zomerski 2016), where Sulikowski is professor of legal theory.

Sub-fields of postmodern and critical legal theory, gradually developing in Central European jurisprudence, include such areas as law and literature (Škop 2011; Škop 2012; Sulikowski 2012b; Mirocha 2013; Klusoňová 2014; Škop 2015; Smejkalová, Škop 2017), law and ideology (Sulikowski 2015; Stambulski 2015; Mańko 2015; Zomerski 2015; Mańko 2016; Gałędek 2017), law and (neo)colonial theory/theories of peripherality (Dębska 2016; Mańko, Škop, Štěpáníková 2016), as well as feminist jurisprudence (Rodak 2014; Dębska 2014; Rodak 2016; Dębska, Warczok 2016; Jedlecka, Helios 2016; Sulikowski 2017). There is a noticeably growing influence of critical sociology (inspired by the legacy of Pierre Bourdieu) and critical discourse analysis (inspired by the works of Norman Fairclough) (Sulikowski 2014) which have been successfully employed especially by Hanna Dębska and Tomasz Warczok and seem to be a promising paradigm for 
invigorating critical legal theory from an empirical perspective (Dębska, Warczok 2014; Dębska 2015). Critical discourse analysis has also been recently employed by Wojciech Zomerski (Zomerski 2017). The concept of "the political", in the sense used by Chantal Mouffe, has been evoked to propose a "political theory of law" (Paździora, Stambulski 2014; Sulikowski, Mańko, Łakomy 2018) conceived as an analysis of the juridical phenomenon through the lens of the political. Recently, it has found its concrete applications in the political theory of judicial decisionmaking (Mańko 2018a; Mańko 2018b). Finally, one should mention a special form of critical legal studies, based on an empirically grounded realist jurisprudence, advanced by Paweł Chmielnicki and a group of researchers following him (Chmielnicki 2015). Chmielnicki's method - situated at the interstices of legal theory and socio-legal studies - is based on analysing the empirically verifiable interests involved in legislative and judicial legal developments, which often leads to questioning the official narrative about the beneficiaries of legal innovations (for instance, a piece of legislation is presented as benefiting consumers, whereas in fact it benefits mainly the banking sector) (Chmielnicki 2014a; Chmielnicki 2014b).

In this context, the present special issue has the ambition of contributing to the further development of critical legal theory of a specific, Central and Eastern European strand, paying attention to the characteristic features of the legal life of our region. The nine papers in this volume can be divided into four distinct groups, addressing issues of our current predicament and its methodological implications (papers by Cercel, Tacik and Mercescu); questions of Central and Eastern European legal identity (paper by myself and by Nazmutdinov); theoretical and philosophical issues particularly in the contemporary Central and Eastern European context (papers by Fusco and Reid); and finally, questions of law and ideology in Central and Eastern Europe analysed through the lens of case studies from various areas of positive law (papers by Kuźmicka-Sulikowska and Rudt). The main question that we want to address is the methodology of critical legal theory as applied to the specific context of Central and Eastern Europe, although the focus of the papers is broader, and some of them already make a tentantive application of critical legal methods to the black-letter law of the region.

In the first paper, entitled 'The Destruction of Legal Reason: Lessons from the Past', Cosmin Cercel (University of Nottingham) addresses the analogies between our present predicament in Central and Eastern Europe to that of the 1930s, viewing the issue from the perspective of jurisprudence. In particular, Cercel argues that there are meaningful analogies between the emergence of post-WWI legal liberalism and the post-1989 legal neoliberalism. Furthermore, he thinks that the roots of the present crisis of legality lie in the liberal legality itself, which merged capitalism, 'rule of law' and parliamentary democracy into one complex, conceptually dependent on the 'markets'. Once the crisis of capitalism unveiled the Real of the markets, the Symbolic order of the juridical started cracking. In 
this context, Cercel argues that the re-emegence of sovereignty and identitarian ideologies in Central and Eastern Europe is not necessarily a regression to a premodern form of legality, but simply a return to the core of liberal legality itself.

In the second paper, entitled 'A New Popular Front, or, on the Role of Critical Jurisprudence under Neo-Authoritarianism in Central-Eastern Europe', Krakówbased philosopher and jurist Przemysław Tacik (Jagiellonian University) addresses the vexed question of the approach of critical jurisprudence towards populism. He argues that critical jurisprudence 'must clearly draw the line between its approach and the manipulative, rightist and nationalist misuse of its heritage', admitting however that '[i]t is not easy to find the correct side of the antagonism'. Nonetheless, in his view 'the Crits must recognise that they belong to the camp of the Enlightenment, together with liberals' and therefore they 'should join the liberal side in defending fundamental values and post-Enlightenment legacy in a kind of tactical popular front'. Tacik's contribution is extremely topical, although I consider that one should not forget about the tensions between liberalism and democracy, highlighted by Mouffe and Laclau already in the 1980s (Laclau, Mouffe 1985). Critical legal theory's committment to authentic, agonistic democracy, means that within the phenomena referred to as instantiations of 'populism' one needs to make a distinction between form and content. In this context, the critique waged by populists against the unrepresentative character of ossified, proceduralised liberal democracy, coupled with the government of judges effectively filling what should be the 'empty place' carries some value. Therefore, as Mouffe rightly points out, the current wave of populism can also be seen as a chance (Mouffe 2018, 84-85).

In the third paper, entitled 'What Kind of Critique for Central and Eastern European Legal Studies? Comparative Law as One of the Answers' Romanian comparatist-at-law Alexandra Mercescu (West University of Timişoara) addresses fundamental questions of legal methodology, arguing that critical comparative law can be an interesting contribution in this respect. In my view, Mercescu's argument is particularly relevant in the context of social and economic antagonisms which are solved in so many different ways in different jurisdictions, to name but the examples of reproduction rights, access to marriage, tenant protection, or workers' participation in the managing of capitalist enterprises (Mitbestimmung). I fully agree that comparative analyses, both within the Central European region and outside of it could point to more progressive solutions, which could be a tangible basis for formulating a constructive critique of the positive law.

The second group of papers, comprising a paper written by myself and a second one by Bulat Nazmutdinov is concerned with the legal identity of Central and Eastern Europe. In my paper entitled 'Delimiting Central Europe as a Juridical Space: A Preliminary Exercise in Critical Legal Geography' I aim at contributing to the on-going discussion, both in legal theory and in comparative law, concerning the status of Central Europe and its delimitation from other legal 
regions in Europe, notably Romano-Germanic Western Europe but also Eastern Europe and Eurasia. The paper adopts the methodological perspective of critical legal geography, understood as a strand of critical jurisprudence laying at the interstices of spatial justice studies, critical geography, comparative law, sociology of law and legal history. The paper proceeds by identifying the notion of Central Europe with reference to a specific list of countries, then proposes six criteria allowing to identify the region's unique legal identity. These include: 1) the dynamic of legal transfers; 2) institutional continuity; 3) legal continuity; 4) legal style; 5) legal ideology; 6) the social role of law. Following that, the paper applies those criteria to the region and enquires as to whether Central Europe should be deemed to be a 'legal family', a 'legal union' or simply a 'legal space' or 'space of legal culture'. In conclusion, I propose to take steps towards building a Central European legal identity which, in turn, could help to combat the region's juridical peripherality and redeploy the energy of the region's legal communities from adapting to the constant influx of foreign legal transfers towards the innovative elaboration of original legal institutions, suited to the needs of Central Europe.

Questions of legal geography are also raised in the fifth paper, authored by Bulat Nazmutdinov, a legal theorist from the Higher School of Economics in Moscow. In his contribution, entitled "Critical Dimensions of the "Legal Culture" Approach: the Case of Classical Eurasianism and Eurasia's Legal Union', he refers to the writings of classical Eurasianists of the 1930s to address the legal identity of the region. He admits, however, that Eurasianism is a typically modernist narrative, based on essentialist assumptions. Nonetheless, he believes it could be usefully deployed towards the construction of a culturalist jurisprudence in our post-modern era.

The following two papers address topics of a general theoretical and philosophical interest which, however, are particularly relevant given Central Europe's present predicament. The paper written by Gian Giacomo Fusco, an Italian philosopher and jurist based at the University of Kent, is entitled 'Ademia: Agamben and the idea of people'. Fusco's intervention is topical in the context of the rise of populism in Central Europe and the reinvigoration of Schmittian friend/ enemy distinctions. The concept of 'ademia', used in the title of the paper, is taken from Giorgio Agamben and means 'absence of a people' (from the Greek $a$ - and demos, a negation of the 'demos'). As Fusco points out, ademia is a constitutive element of the modern state according to Agamben. In his paper, Fusco analyses the concept of ademia and its theoretical unfolding, as well as reconsiders it in the context of different interpretations of the idea of the demos, especially those of Rousseau and Schmitt. He argues that the notion of ademia can be of assistance in comprehending the paradoxical nature of the uses of the idea of the people in contemporary political discourse. Fusco concludes by stating that 'in light of what has been done in name of the people and the resurgence of fascio-populist sentiments, the challenge for contemporary political imagination, is not to question 
the validity of the political category of the "people"; perhaps the time has come for thinking a politics completely detached from any idea of the people.' This finding seems to be very relevant in today's Central and Eastern European context, where populist discourse is reviving ethnonationalist forms of identity and reinvigorating Schmittian lines of division into friends (members of the ethnonationalist and sectarian community) and enemies (all those who are not in that community). The dangers of this discourse and its possibly tragic consequences are all too well known from legal and political history.

The paper by Julian Reid, a British political scientist based at the University of Lapland (Finland), addresses questions of ideological narratives concerning poverty with particular reference to the situation in Central and Eastern Europe. Reid's paper shows the different ways in which the poor are being put to work, in defence of a global neoliberal order by international economic institutions concerned with constructing them as so-called 'resilient' subjects. In his view, this predicament of the poor is particularly vexed in Eastern Europe where strategies of resilience are fast developing, and critical legal theory has so far offered little resistance to this trend. The article considers how one might reimagine poverty and conceive its politics beyond and against clichéd images of the poor as 'resilient' subjects.

The last two papers are case studies on law and ideology. The first one, written by private lawyer Joanna Kuźmicka-Sulikowska (University of Wrocław) focuses on 'The Politics of Limitation of Claims in Poland: Post-Communist Ideology, Neoliberalism and the Plight of Uninformed Debtors'. The object of Kuźmicka-Sulikowska's case study is a rather technical rule of the Polish Civil Code concerning the statute of limitations (prescription of claims) and, more specifically, whether courts may apply limitation on their own motion, or only upon request of one of the parties. Heeding to Duncan Kennedy's claim that there is always something political in the allegedly 'merely technical' rules of private law, Kuźmicka-Sulikowska tells the story of the ideological and social stakes behind the recent changes of the legislation concerning the statute of limitations. The Central European context of rejecting, after 1989, everything that is socialist, has played an important role in the developments, just as the populist tendencies of more recent pedigree.

The last paper in this special issue, written by Yulia Rudt from the Novosibirsk University of Technology, is concerned with 'Ideology in Modern Russian Constitutional Practice'. Rudt analyses the case-law of the Russian Constitutional Court from a law and ideology research perspective. In her view, the Court 'relies on ideologies of formalism and rationalism as adapted to the current economic, political and social development in Russia' as well as 'follows the idea around one truth in constitutional cases with the presumption that this truth is included in the axiomatically legitimate aim of legislators of Russia', i.e. follows the ideology of objectivism in legal interpretation (cf. Rodak, Żak 2015). Nonetheless, she also 
notes a partial reception of Western constitutional doctrines, such as the principle of proportionality or the balancing of public and private interests.

$$
* * *
$$

I hope that the present special issue will constitute a further step in the development of critical legal theory in Central and Eastern Europe, following two special issues of journals (special issue of Archiwum Filozofii Prawa i Filozofii Społecznej volume 8 issue 1 of 2014, edited by Paweł Skuczyński, devoted to law and critical theory; special issue of the Wroclaw Review of Law, Administration and Economics, volume 5 issue 1 of 2015, edited by Michał Stambulski and myself, devoted to law and ideology), as well as two edited volumes (Mańko, Cercel, Sulikowski 2016; Bieś-Srokosz, Mańko, Srokosz 2019). As critical legal scholars, we need to take Central European specificities very seriously and, at the same time, we should be aware of the risks of applying and propagating critical legal tools, which are, as it is well known, sometimes abused by the populists (Zomerski 2018, 101). This does not mean that we should suspend or repress the development of critical legal theory in Central and Eastern Europe. To the contrary, we should take stock of the moment and work towards adapting the critical legal instrumentarium to the needs of the time and place. The current crisis of neoliberal legality creates a unique opportunity that we must definitely utilise to our advantage.

\section{BIBLIOGRAPHY}

Bieś-Srokosz, Paulina. Rafał Mańko. Jacek Srokosz. Eds. 2019. Law, Space and the Political: An East-West Perspective. Częstochowa: Podobiński Publishing House.

Chmielnicki, Paweł. 2014a. "Źródła i efektywność regulacji dotyczących nabycia lokalu lub domu od dewelopera. Ocena wstępna”. Przeglad Prawa Publicznego 7/8: 141-156.

Chmielnicki, Paweł. 2014b. Nabycie lokalu lub domu od dewelopera. Wyktadnia przepisów i efekty ich stosowania. Warszawa: Difin.

Chmielnicki, Paweł. 2015. "The Research Method of Association for the Research on Sources and Functions of Law". Przeglad Prawa Publicznego 3: 95-105.

Dębska, Hanna. 2014. "Płeć i władza. Kobiety w Trybunale Konstytucyjnym”. Studia Podlaskie 22: 91-111.

Dębska, Hanna. 2015. Władza, symbol, prawo. Społeczne tworzenie Trybunału Konstytucyjnego. Warszawa: Wydawnictwo Sejmowe.

Dębska, Hanna. 2016a. "Prawo jako pole (ujęcie modelowe)". Państwo i Prawo 9: 36-53.

Dębska, Hanna. 2016b. "Strategia wielopozycyjności w półperyferyjnym polu prawnym. Homo academicus na rynku”. In Polska jako peryferie. 221-240. Edited by Tomasz Zarycki. Warszawa: Scholar.

Dębska, Hanna. Tomasz Warczok. 2014. "Sacred Law and Profane Politics. The Symbolic Construction of the Constitutional Tribunal”. Polish Sociological Review 4: 465-478. 
Dębska, Hanna. Tomasz Warczok. 2016. "The Social Construction of Feminity in the Discourse of the Polish Constitutional Court". In Law and Critique in Central Europe: Questioning the Past, Resisting the Present. 106-30. Edited by Rafał Mańko, Cosmin Cercel, Adam Sulikowski. Oxford: Counterpress.

Douzinas, Costas. 2014. "A Short History of the British Critical Legal Conference or, the Responsibility of the Critic". Law and Critique 25(2): 187-198.

Gałędek, Michał. 2017. "Juridification as an Ideology of Polizeiwissenschaft in 18th Century". Journal on European History of Law 8(1): 76-84.

Jedlecka, Wioletta. Joanna Helios. 2016. Wptyw feminizmu na sytuacje społeczno-prawna kobiet. Wrocław: Prawnicza i Ekonomiczna Biblioteka Cyfrowa.

Kennedy, Duncan. 2001. "The Political Stakes in 'Merely Technical' Issues of Contract Law". European Review of Private Law 1: 7-28.

Klusoňová, Marketa. 2014. "Is Hamlet a Scandinavian Crime Fiction?" Wroclaw Review of Law, Administration \& Economics 5(1): 104-118.

Laclau, Ernesto. Chantal Mouffe. 1985. Hegemony and Socialist Strategy: Towards a Radical Democratic Politics. London-New York: Verso.

Mańko, Rafał. 2015. "Reality is for Those who Cannot Sustain the Dream: Fantasies of Selfhood in Legal Texts". Wroclaw Review of Law, Administration and Economics 5(1): 24-47.

Mańko, Rafał. 2016. "Ideology and Legal Interpretation: Some Theoretical Considerations". In Constitutional Values in Contemporary Legal Space. Vol. 1. 121-123. Edited by Kalvis Torgans. Riga: University of Latvia Press.

Mańko, Rafał. 2018a. W strone krytycznej filozofii orzekania. Polityczność, etyka, legitymizacja. Łódź: Wydawnictwo Uniwersytetu Łódzkiego.

Mańko, Rafał. 2018b. "Orzekanie w polu polityczności”. Filozofia Publiczna i Edukacja Demokratyczna 7(1): 65-95.

Mańko, Rafał. Cosmin Cercel. Adam Sulikowski. Eds. 2016. Law and Critique in Central Europe: Questioning the Past, Resisting the Present. Oxford: Counterpress.

Mańko, Rafał. Martin Škop. Markéta Štěpáníková. 2016. "Carving out Central Europe as a Space of Legal Culture: A Way Out of Peripherality?" Wroclaw Review of Law, Administration and Economics 6(2): 3-28.

Mirocha, Łukasz. 2013. "Law and literature jako niedoceniony nurt jurysprudencji". Societas et Ius 1(2): 82-97.

Morawski, Lech. 2001. Co może dać nauce prawa postmodernizm? Toruń: TNOiK.

Mouffe, Chantal. 2018. For a Left Populism. London-New York: Verso.

Oliwniak, Sławomir. 2003a. "Transgresja, dyskurs, prawo w ujęciu Michela Foucaulta". In Filozofia prawa wobec globalizmu. 207-221. Edited by Jerzy Stelmach. Kraków: Wydawnictwo Uniwersytetu Jagiellońskiego.

Oliwniak, Sławomir. 2003b. "Michel Foucault a potrzeba nauczania filozofii prawa". In Filozofia prawa w życiu i nauczaniu. 68-84. Edited by Maria Szyszkowska. Białystok: Temida2.

Oliwniak, Sławomir. 2006. "Etyka siebie. Dokończony projekt oświecenia Michela Foucaulta". In Człowiek wobec systemów wartości. 44-55. Edited by Tomasz Kozłowski, Karol Kuźmicz. Białystok: Temida2.

Oliwniak, Sławomir. 2009. "Biopolitics and the Rule of Law". Studies in Logic, Grammar and Rhetoric 32: 33-48.

Oliwniak, Sławomir. 2010. "Giorgio Agamben: biopolityka i 'pusta' forma prawa". In Dyskrecjonalność w prawie. 540-549. Edited by Wiesław Staśkiewicz, Tomasz Stawecki. Warszawa: LexisNexis.

Oliwniak, Sławomir. 2011. "Foucault and Agamben: Law As Inclusive/Exclusive Discourse". Studies in Logic, Grammar and Rhetoric 39: 49-62. 
Paździora, Michał. Michał Stambulski. 2014. “Co może dać nauce prawa polityczność? Przyczynek do dalszych badań". Archiwum Filozofii Prawa i Filozofii Społecznej 8(1): 55-66.

Rodak, Lidia. 2014. "Are we all feminists now? Wyzwania ze strony Feministycznej Jurysprudencji wobec tradycyjnej teorii prawa". Archiwum Filozofii Prawa i Filozofii Spolecznej 8(1): 67-76.

Rodak, Lidia. 2016. "Structural Violence and Its Gender Dimension in Polish Law". In Law and Critique in Central Europe: Questioning the Past, Resisting the Present. 131-53. Edited by Rafał Mańko, Cosmin Cercel, Adam Sulikowski. Oxford: Counterpress.

Rodak, Lidia. Piotr Żak. 2015. "Justice and Objectivity as Balancing Principles". Wroclaw Review of Law, Administration and Economics 5(1): 79-94.

Škop, Martin. 2011. "Milan Kundera and Franz Kafka - How Not to Forget Everydayness". Creative and Knowledge Society 1(2): 110-119.

Škop, Martin. 2012. "Pluralism of Values in Contemporary Law and Possibility of Their Cognition". Przeglad Prawa i Administracji 90: 109-117.

Škop, Martin. 2015. "Law and Literature a Meaningful Connection”. Filozofia Publiczna i Edukacja Demokratyczna 4(1): 6-20.

Smejkalová, Terezie. Martin Škop. 2017. “A Concept of a Reader in Legislation Drafting”. In: Argumentation 2017. 51-69. Edited by Markéta Štěpáníková, Michal Malaník, Monika Hanych, Martin Škop. Brno: Masaryk University.

Stambulski, Michał. 2015. "The Critique of Ideological Legal Reason". Wroclaw Review of Law, Administration and Economics 5(1): 48-60.

Sulikowski, Adam. 2006a. "Nowoczesność i ponowoczesność w pojmowaniu prawa". Zeszyty Naukowe Watbrzyskiej Wyższej Szkoły Zarządzania i Przedsiębiorczości 2: 119-127.

Sulikowski, Adam. 2006b. "O ponowoczesnej teorii prawa". In W poszukiwaniu podstaw prawa. 243-258. Edited by Adam Sulikowski. Wrocław: Wydawnictwo Uniwersytetu Wrocławskiego.

Sulikowski, Adam. 2007a. "Poststrukturalistyczne pojmowanie prawa w myśli M. Foucaulta". Zeszyty Naukowe Watbrzyskiej Wyższej Szkoły Zarządzania i Przedsiębiorczości 1: 174-182.

Sulikowski, Adam. 2007b. "Derridiańska koncepcja prawa”. Zeszyty Naukowe Wałbrzyskiej Wyższej Szkoły Zarządzania i Przedsiębiorczości 1: 166-173.

Sulikowski, Adam. 2010a. "O możliwościach postmodernizacji nauki prawa konstytucyjnego". Państwo i Prawo 12: 3-16.

Sulikowski, Adam. 2010b. "Opresywność pozytywizmu prawnego i jego postmodernistyczna krytyka”. In Pozytywizm prawniczy i szkoła prawa natury - tradycje sporu i jego wspótczesne implikacje. 28-35. Edited by Przemyław Kaczmarek, Łukasz Machaj. Wrocław: Prawnicza i Ekonomiczna Biblioteka Cyfrowa.

Sulikowski, Adam. 2012a. Konstytucjonalizm a nowoczesność: dyskurs konstytucyjny wobec tryumfu i kryzysu moderny. Wrocław: Wydawnictwo Uniwersytetu Wrocławskiego.

Sulikowski, Adam. 2012b. "Literary Fiction in Legal Dogmatics in Continental European Constitutional Law". Acta Universitatis Brunensis. Iuridica 432: 45-52.

Sulikowski, Adam. 2013. Posthumanizm a prawoznawstwo. Opole: Wydawnictwo Uniwersytetu Opolskiego.

Sulikowski, Adam. 2014. "Perspektywy zastosowań metod Krytycznej Analizy Dyskursu w badaniach nad prawem. Kilka uwag”. Studia Erasmiana Wratislawiensia 8: 99-111.

Sulikowski, Adam. 2015. "Prawa a ideologia: prawa jednostki z perspektywy krytycznej myśli prawniczej i społecznej (wybrane zagadnienia)". Roczniki Nauk Społecznych 4: 17-32.

Sulikowski, Adam. 2017. "Prawo i płeć: kilka uwag o potencjale krytycznym feministycznej jurysprudencji”. Wrocławsko-Lwowskie Zeszyty Prawnicze 8: 85-101.

Sulikowski, Adam. Rafał Mańko. Jakub Łakomy. 2018. "Polityczność prawa i ogólnej refleksji nad prawem: wprowadzenie”. Archiwum Filozofii Prawa i Filozofii Spolecznej 3: 5-9. 
Wojciechowski, Bartosz. 2019. "Dekonstrukcja między prawem a sprawiedliwością". In Zmiany społeczne a zmiany w prawie. 305-315. Edited by Leszek Leszczyński. Lublin: UMCS.

Zomerski, Wojciech. 2015. "Ideology in Modern Times: Three Ideological Lies Behind Universal Human Rights". Wroclaw Review of Law, Administration and Economics 5(1): 119-127.

Zomerski, Wojciech. 2016. "Conference report: 1st International Conference of the Central European Network of Legal Scholars (CENELS) on '25 Years After the Transformation: Law and Legal Culture in Central and Eastern Europe. Between Continuity and Discontinuity', Masaryk University, Brno, Czech Republic, 16-17 April 2015”. Wroclaw Review of Law, Administration and Economics 4(2): 103-108.

Zomerski, Wojciech. 2017. "Krytyczna analiza dyskursu sądowego dotyczącego prawnej sytuacji osób homoseksualnych w świetle art. 18 Konstytucji RP”. Archiwum Filozofii Prawa i Filozofii Społecznej 2: 80-97.

Zomerski, Wojciech. 2018. "Czy Europie Środkowej potrzebna jest krytyczna teoria prawa? (artykuł recenzyjny)". Państwo i Prawo 9: 95-108. 